\title{
Coffee Berry Borer (Hypothenemus Hampei Ferr.) Attacks in Organic and Conventional Arabica Coffee Plantations
}

\author{
Husni, Sapdi, Jauharlina, Alfian Rusdy, Elka Mulyadi \\ Plant Protection Department, Agriculture Faculty Syiah Kuala University, Banda Aceh, \\ Indonesia. \\ \{proteksi.tanaman@unsyiah.ac.id\}
}

\begin{abstract}
We have conducted a series of studies on Arabica coffee plantations in Aceh Tengah Regency, Aceh Province, Indonesia to study the effect of organic and conventional coffee plantation systems on the level of attack by coffee berry borer (CBB), Hypothenemus hampei. The results showed that at each observation the level of $\mathrm{CBB}$ attacks on coffee plants cultivated organically was lower than those cultivated conventionally. The level of CBB attack on organic and conventional coffee plantations is between $7.9-12.1 \%$ and $13.2-22.2 \%$ respectively. From the results of this study, it is suspected that in coffee plantations that are cultured organically there are more diverse or more abundant organisms that act as natural enemies, so they can suppress CBB population development. Meanwhile, conventional coffee cultivation is suspected to have decreased the natural enemy population of $\mathrm{CBB}$, because on these lands synthetic pesticides have been used continuously to control various disturbing organisms in coffee plants. The results of this study indicate that organic coffee farming systems have played an important role in maintaining the biodiversity of various organisms in coffee plantations, so that the population development of various coffee plant pests, i.e. $\mathrm{CBB}$ can be balanced by the development of their natural enemy population.
\end{abstract}

Keywords: Arabica coffee, organic and conventional coffee plantation, Hypothenemus hampei

\section{Introduction}

Data Coffee berry borer (CCB) is the most dangerous insect pest in coffee plants [1]-[5]. The coffee berry borer (CBB), Hypothenemus hampei, is the most significant insect pest of coffee worldwide.

CCB (Hypothenemus hampei) originated in Central Africa, was first discovered in a coffee plantation on the island of Java in 1909 [1]. As a result of this pest, attack has caused a decrease in the production of coffee beans both in quantity and quality. Due to this pest attack, coffee production can decrease by up to 50\% [6]. Barrera (2008) reports that loss of results due to CCB attacks can reach $30-35 \%$, even in the harvest season can reach $100 \%$.

This pest attack from year to year continues to increase, even these pests are reported to have attacked coffee plants planted at an altitude of $1500 \mathrm{~m}$ above sea level. The effects of global warming are thought to have triggered an increase in insect pest attacks on various crops grown in the highlands, including coffee plants. The use of synthetic insecticides to control these pests is not recommended, because in addition to being ineffective it can also adversely affect humans and the surrounding environment. Therefore, it is necessary to look for other alternatives to control these pests. 
One alternative that is very possible is to empower the natural enemies of CCB pests that are inside the coffee plantation area. These domestic natural enemies can be predators, parasitoid insects, or entomopathogens. These biocontrol agents will be able to suppress the development of pest populations if supported by good environmental conditions, namely the environment that is free from the contamination of harmful chemical compounds, especially those derived from pesticides. The only system that allows for the preservation of biocontrol agents on agricultural land is the organic farming system. The organic farming system is an agricultural system that does not use harmful chemicals at all, either from pesticides or synthetic fertilizers. Human awareness of the importance of applying organic farming systems is triggered by their awareness of the dangers of synthetic chemical compounds to humans and the environment. Now there are several agricultural commodities that apply organic farming systems, one of which is coffee plants.

One area of an organic coffee plantation that is quite extensive is in Aceh Tengah District, Aceh Province, Indonesia. In the area, it has been cultivated more than 13,000 Ha of Arabica coffee plants organically (Disbunhut Kab.Aceh Tengah, 2015). One reason farmers in this area grow coffee organically is because the selling price of organic coffee beans is much higher than conventional ones. Arabica coffee is the main export commodity in this region. The reason for the higher selling price of organic coffee is because organic coffee is considered safer to consume, especially by consumers abroad.

Organic coffee cultivation is not only economically beneficial but also ecologically, because the organic farming system does not negatively affect the environment. Conversely, conventional farming systems are thought to have triggered environmental damage, both biotic and abiotic. Quite a lot of research reports on the occurrence of pest explosion cases that occur more often in agricultural areas that are routinely sprayed with pesticides, because of the occurrence of pest resurgence and resistance.

In connection with this, we have conducted a series of observations to see a comparison of the level of CBB pest attacks between Arabica coffee plantations that are managed organically with conventional ones.

\section{Material and Methods}

\subsection{Selection of Research Plot Location}

In determining the research plot, the general conditions of the research location and environmental factors, such as the altitude of the sea level, shade plants, and the age of the sample plants are as homogeneous as possible. Therefore, mapping of the area was carried out by measuring the altitude of each research location using GPS. The sampling location was selected for coffee plantations that were managed conventionally and organically at an altitude of 1,100 - 1,300 m above sea level with an area of at least $10 \mathrm{Ha}$. Generally, the coffee plantation area in Aceh Tengah Regency is at this altitude, which is the most ideal condition for the growth of Gayo arabica coffee. The area of each research plot is 1 Ha with a total of 20 sample plants per plots randomly zigzagged, so there are 20 organic and 20 non-organic sample plants respectively.

\subsection{Observation}

The observation period is carried out 3 (three) times, namely before the harvest period, during the harvest and after the harvest, with a number of observations each period of 2 (two) 
times. To calculate the level of CBB attack from each sample tree 200 pieces of coffee were taken randomly from each sample tree. The level (percentage) of an attack is calculated using the formula:

$$
P=a / b X 100 \%
$$

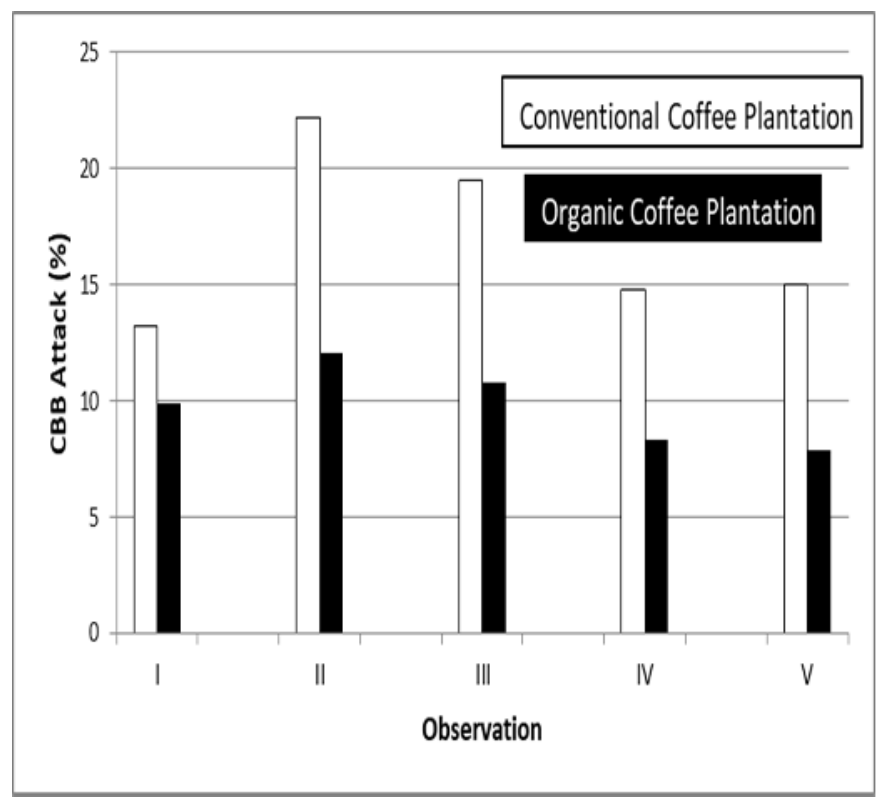

Figure 1. Coffee berry borer attack in conventional and organic coffee plantation P:

P:Percentage of infected fruit

a: The amount of sample fruit attacked

b: The total number of samples

\section{Results and Discussion}

The results showed that in general the percentage of coffee berry attacked by CBB on organic coffee plantations was lower than conventional ones. The level of CBB attack on organic and conventional coffee plantations is between $7.9-12.1 \%$ and $13.2-22.2 \%$ respectively (Fig. 1). In organically managed coffee plantations, it is suspected that there are many organisms that act as biological control agents that can suppress CBB pest populations so that the level of $\mathrm{CBB}$ attacks is lower than conventional coffee plantations. Research conducted by Hamdi, Sapdi, \& Husni (2015) on Arabica coffee plantations in Aceh Tengah Regency, also showed that the level of diversity of various species of Hymenoptera parasitoid was much higher in coffee plantations that were managed organically than coffee plantations that were managed inorganically. Individual abundance, number of families and higher wealth of Hymenoptera species are found in coffee cultivation practices organically compared to conventional coffee plantations. The composition of Hymenoptera parasitoid in coffee plantations that are managed organically consists of 13 families, while in coffee gardens conventionally managed only consists of 7 families [9]. Various studies reviewed related to 
the influence of organic and conventional farming systems on insect populations. The results of the review show that in organic farmland species richness and abundance of insect populations are higher compared to conventional agricultural land [10]. The research conducted by Chau \& Heong (2005) on rice plants also shows that organically grown rice plants have a lower rate of pest and disease attack than rice plants grown conventionally, and their productivity was not significantly different from those planted conventionally.

In our preliminary experiments also shows that in coffee plantations that are managed organically the level of diversity and number of Arthropod species that act as predators and parasitoids is much higher than conventional coffee plantations [9]. This indicates that the application of various synthetic pesticides in conventional coffee plantations has a negative impact on Arthropods which acts as a natural enemy in coffee plants. Quite a lot of broad spectrum pesticides such as organophosphate have disrupted the existence of various beneficial species, such as natural enemies and have also caused secondary pest outbreaks [12]. In our previous study Hamdi et al., (2015) we found a parasitoid species that was once released in a coffee plantation in Aceh Tengah Regency, namely Phoropo nasuta (Hymenoptera: Bethylidae). This parasitoid was released by the Aceh Tengah Regency Plantation and Forestry Service (Disbunhut Kab.Aceh Tengah, 2015) several years ago to control CBB pests. It is suspected that the presence of this parasitoid in coffee plantations in Aceh Tengah Regency has helped suppress CBB pest population. Of course, further research is needed to find the most potential domestic natural enemies to control this CBB pest. The results of this study have also been able to answer the benefits of organic coffee cultivation, which is in addition to ensuring the avoidance of coffee beans from the contamination of harmful chemical compounds, is also able to reduce the level of CBB pest attacks.

\section{REFERENCES}

[1] L. G. E. Kalshoven, The pests of crops in Indonesia. Jakarta: Van Hoeve: P. T. Ichtiar Baru, 1981

[2] E. Burbano, M. Wright, D. E. Bright, and F. E. Vega, "New record for the coffee berry borer, hypothenemus hampei, in Hawaii," J. Insect Sci., vol. 11, no. 1, 2011.

[3] R. H. Messing, "The coffee berry borer (hypothenemus hampei) invades Hawaii: Preliminary investigations on trap response and alternate hosts," Insect, vol. 3, no. 3, pp. 640-652, 2012.

[4] C. K. Vijayalakshmi, K. Tintumol, and U. Saibu, "Coffee berry borer, hypothenemus hampei (ferrari): A review," Int. J. Innov. Res., vol. 2, no. 13, pp. 358-361, 2013.

[5] L. Aristizábal et al., "Integrated pest management of coffee berry borer in hawaii and puerto rico: Current status and prospects," Insect, vol. 8, no. 4, 2017.

[6] T. Wahyudi and Misnawi, "Fasilitasi perbaikan mutu dan produktivitas kakao indonesia," War. Pus. Penelit. Kopi dan Kakao Indones., vol. 23, no. 1, pp. 32-43, 2007.

[7] J. F. Barrera, Coffee pests and their management. Mexico, 2008.

[8] Disbunhut Kab.Aceh Tengah., "Data perkembangan luas areal dan produksi tanaman tahunan dan semusim komoditi perkebunan 7 tahun terakhir (2009-2015) Kabupaten Aceh Tengah," Dinas Perkebunan dan Kehutanan Kabupaten Aceh Tengah., 2015.

[9] S. Hamdi, Sapdi, and Husni, "Komposisi dan struktur komunitas parasitoid hymenoptera antara kebun kopi yang dikelola secara organik dan konvensional di Kabupaten Aceh Tengah,” J. Floratek, vol. 10, no. 2, pp. 44-51, 2015.

[10] M. N. Montañez and Á. Amarillo-Suárez, "Impact of organic crops on the diversity of insects: A review of recent research ," Rev. Colomb. Entomol., vol. 40, no. 2, pp. 131- 
$142,2014$.

[11] L. M. Chau and K. L. Heong, "Effects of organic fertilizers on insect pest and diseases of rice," Omonrice, pp. 26-33, 2005.

[12] M. Hill, S. Macfadyen, and M. Nash, "Broad spectrum pesticide application alters natural enemy communities and may facilitate secondary pest outbreaks," PeerJ, 2017. 